\title{
An advanced lentil backcross population developed from a cross between Lens culinaris $\times$ L. ervoides for future disease resistance and genomic studies
}

Tadesse S Gela*, Stanley Adobor, Hamid Khazaei and Albert Vandenberg*

Department of Plant Sciences, University of Saskatchewan, 51 Campus Drive, Saskatoon, Saskatchewan, S7N 5A8, Canada

\section{Running title: An advanced backcross population in lentil}

*Corresponding authors: tsg688@mail.usask.ca; bert.vandenbarg@ usask.ca

\begin{abstract}
Genetically accessible variation to some of the abiotic and biotic stresses are limited in the cultivated lentil (Lens culinaris Medik.) germplasm. Introgression of novel alleles from its wild relative species might be required for enhancing the genetic improvement of the crop. L. ervoides, one of the wild relatives of lentil, is a proven source of disease resistance for the crop. Here we introduce a lentil advanced backcross population (LABC-01) developed in cultivar CDC Redberry background, based on $L$. ervoides alleles derived from an interspecific recombinant inbred population, LR-59-81. Two-hundred and seventeen individuals of the $\mathrm{LABC}-01$ population at $\mathrm{BC}_{2} \mathrm{~F}_{3: 4}$ generation were screened for the race 0 of anthracnose (Colletotrichum lentis) and stemphylium blight (Stemphylium botryosum) under controlled conditions. The population showed significant variations for both diseases and transfer of resistance alleles into the elite cultivar was evident. It also segregated for other traits such as days to flowering, seed coat colour, seed coat pattern and flower colour. Overall, we showed that LABC-01 population can be used in breeding programs worldwide to improve disease resistance and will be available as a valuable genetic resource for future genetic analysis of desired loci introgressed from L. ervoides.
\end{abstract}

Keywords: crop wild relatives, Lens spp., mapping population, pre-breeding, biotic stresses 


\section{Introduction}

Cultivated lentil (Lens culinaris Medik.) is an economically important cool-season grain legume with genome size of $\sim 4.3 \mathrm{Gbp}$ in the haploid complement (Bett et al., 2016). The crop is cultivated in more than 70 countries worldwide and the production (2015-2019 average) from Canada (40\%), India (19\%) and Australia (9\%) provides most of the world's supply. Average global annual production was around 6.3 Mt (FAOSTAT, 2021). A genetic bottleneck limiting genetic variability exists in cultivated lentil germplasm (Erskine et al., 1994, 1989; Gupta and Sharma, 2006; Khazaei et al., 2016). Broadening the genetic base of breeding programs by introducing new genetic resources is required for development of improved lentil germplasm. Crop wild relatives have been used to improve the resistance and resilience of elite cultivars against various biotic and abiotic stresses in many crops (Hajjar and Hodgkin, 2007) including grain legumes (Pratap et al., 2021).

The Lens genus has seven closely related taxa; L. culinaris, L. orientalis (Boiss.) Hand.-Maz., L. tomentosus Ladiz. (primary gene pool); L. odemensis Ladiz., L. lamottei Czefr. (secondary gene pool); L. ervoides (Brign.) Grand. (tertiary gene pool); and L. nigricans (M.Bieb.) Grand. (quaternary gene pool, see Wong et al., 2015). Among them, L. ervoides has been identified as a potential source of desirable genes for resistance to major lentil diseases such as anthracnose (Colletotrichum lentis Damm) (Tullu et al., 2006; Vail et al., 2012), ascochyta blight (Ascochyta lentis Vassilievsky) (Tullu et al., 2010), stemphylium blight (Stemphylium botryosum Wallr.) (Podder et al., 2013), and fusarium wilt (Fusarium oxysporum f. sp. lentis) (Singh et al., 2017) along with yield and its components (Gupta and Sharma, 2006; Tullu et al., 2011; Tullu et al., 2013; Chen, 2018), and abiotic stresses (Gorim and Vandenberg, 2017; Yuan et al., 2017). Introgression of the desirable alleles from L. ervoides to L. culinaris elite germplasm were 
facilitated by embryo/ovule rescue techniques that overcome the interspecific reproductive barriers (Fiala et al., 2009; Tullu et al., 2013). However, the introgressed gene from a distant wild relative into elite cultivars may result in disruption of the long-accumulated agronomic and quality traits due to linkage drag and/or epistatic interactions of deleterious genes of undesired wild traits (Tanksley et al., 1989; Tanksley and Nelson, 1996). In many cases, these undesired traits are dominant and polygenic, making it difficult to select against and impeding the interspecific hybrid progeny from direct use in the breeding programs. In lentil, Tullu et al. (2013) and Chen (2018) reported the presence of undesired traits such as seed dormancy, poor emergence, extremely small seed size, and pod dehiscence in L. ervoides interspecific lines.

The advanced backcross $(\mathrm{AB})$ populations are developed through multiple backcrossing $\left(\mathrm{BC}_{2}\right.$ or $\mathrm{BC}_{3}$ ) followed by multiple rounds of selfing, and they may contain single or multiple, fixed, or non-fixed segments of the introgressed genome of the wild species (Fulton et al., 1997). The AB lines are useful genetic materials for the development of introgression lines, which consist of fixed lines that are carrying a single or a few genomic segments associated with desired traits (Frischa et al., 1999, Prohens et al., 2017, Dempewolf et al., 2017). To make the introgression process more efficient and applicable, Tanksley and Nelson (1996) proposed an advanced backcross-quantitative trait loci (AB-QTL) mapping approach as a tool to minimize the undesirable segments of the wild genome through repeated backcrossing to the elite cultivar and simultaneous mapping of QTL underlying the trait of interest. The AB-QTL strategy has been used in many crop species for identifying introgression QTL for many traits of interest (reviewed by Bhanu et al., 2017) including disease resistance (Yun et al., 2006; Schmalenbach et al., 2008; Taguchi-Shiobara et al., 2013). 
Here we introduce a lentil advanced backcross population (LABC-01) derived from a cross

between the CDC Redberry and an interspecific line, LR-59-81 developed from L. ervoides. This population offers an opportunity to utilize beneficial traits introgressed from lentil wild relatives. As a showcase, the responses of the $\mathrm{LABC}-01$ population at $\mathrm{BC}_{2} \mathrm{~F}_{3: 4}$ generation to anthracnose race 0 and stemphylium blight under climate-controlled conditions are presented.

\section{Experimental details}

\section{Parental lines selection}

A lentil advanced backcross population (LABC-01) was developed from two founder lines, CDC Redberry and LR-59-81 (Figure 1A). The recurrent parent, CDC Redberry, was a red lentil cultivar released by the Crop Development Center (CDC), University of Saskatchewan (USask) for its high yield and partial resistance to anthracnose race 1 and ascochyta blight (Vandenberg et al., 2006). CDC Redberry was used to develop a lentil reference genome (Bett et al., 2016). The line LR-59-81 was selected from the LR-59 interspecific recombinant inbred line (RIL) population (Fiala et al., 2009), which was developed from a cross between L. culinaris cv. Eston $\times$ L. ervoides accession L-01-827A (Figure 1B). Embryo rescue techniques were used to obtain the $\mathrm{F}_{1}$ seeds (Fiala et al., 2009). Line LR-59-81 was evaluated for resistance to anthracnose (race 0 and 1), ascochyta blight and stemphylium blight (Table 1) and has been commonly used as a source of resistant for both races of anthracnose (Banniza et al., 2018; Gela et al., 2020).

\section{LABC-01 population development}

The LABC-01 population was developed by crossing CDC Redberry $\times$ LR-59-81 to obtain the $F_{1}$ generation (Figure $1 A$ ). All $F_{1}$ seeds were fertile and hybridity of $F_{1}$ plants was confirmed by flower colour as a morphological marker. CDC Redberry had typical L. culinaris flower-type, 
white background with light blue veins and LR-59-81 had purple flowers (typical L. ervoides). All $\mathrm{F}_{1}$ plants had purple flowers. Purple flower colour was dominant over white with blue veins and it is known to be inherited as a simple Mendelian fashion (Singh et al., 2014). Two $\mathrm{F}_{1}$ plants were backcrossed to $\mathrm{CDC}$ Redberry to obtain $\mathrm{BC}_{1} \mathrm{~F}_{1}$ seeds. To avoid genetic drift, all efforts were made to achieve the maximum number of cross combinations. A total of 111 and $73 \mathrm{BC}_{1} \mathrm{~F}_{1}$ seeds were harvested from two $\mathrm{F}_{1}$ plants, respectively. The segregation of the flower colours was checked for the $\mathrm{BC}_{1} \mathrm{~F}_{1}$ population and fit a 1:1 ratio ( 88 white: 93 purple, chi-square $\left(\chi^{2}\right)_{(1: 1)}=$ $0.138, P=0.710$ ), indicating unbiased segregation of the $\mathrm{BC}_{1} \mathrm{~F}_{1}$. The second backcross was made independently with all $184 \mathrm{BC}_{1} \mathrm{~F}_{1}$ plants to generate the $\mathrm{BC}_{2}$ population, and one to two $\mathrm{BC}_{2} \mathrm{~F}_{1}$ seeds were advanced to $\mathrm{BC}_{2} \mathrm{~F}_{2}$ for each successful $\mathrm{BC}_{1} \mathrm{~F}_{1}$ backcross. A total of $217 \mathrm{BC}_{2} \mathrm{~F}_{2}$ individuals was generated and one seed of each individual was arbitrarily selected and selfed to generate the $\mathrm{BC}_{2} \mathrm{~F}_{3}$ generation and onward using a single seed descent approach.

\section{Growth conditions}

In all experiments, the growth chamber conditions were adjusted to $18 \mathrm{~h}$ light and $6 \mathrm{~h}$ dark, with the temperatures maintained at $21^{\circ} \mathrm{C}$ (day) and $18{ }^{\circ} \mathrm{C}$ (night) and the photosynthesis photon flux density was set to $300 \mu \mathrm{mol} \mathrm{m} \mathrm{m}^{-2} \mathrm{~s}^{-1}$ during the light period at the crop canopy level. All experiments were carried out at the controlled-climate growth chambers at USask College of Agriculture and Bioresources phytotron facility, Saskatoon, Canada.

\section{Disease phenotyping}

\section{Phenotyping for anthracnose resistance}

A total of $217 \mathrm{BC}_{2} \mathrm{~F}_{3: 4}$ individuals of the LABC-01 population and parental lines were evaluated for anthracnose race 0 under growth chamber conditions. Fungal inoculum production, 
inoculation and plant growth conditions were performed as described by Gela et al. (2020).

Briefly, two plants of each line were grown in a set of 38 -cell cone trays $(26.8 \times 53.5 \mathrm{~cm})$ per replication filled with SUNSHINE Mix \#4 plant growth medium (Sun Gro Horticulture, Seba Beach, AB, Canada) and perlite (Specialty Vermiculite Canada, Winnipeg, MB) in a 3:1 ratio (v/v). The susceptible control cv. Eston (Slinkard, 1981) and the parental lines were included in each tray. The experiment design was a randomized complete block (RCBD) with seven replicates. Replicates were inoculated over time. Four-week-old seedlings were inoculated with a spore suspension $\left(5 \times 10^{4}\right.$ spores $\left.\mathrm{mL}^{-1}\right)$ of $C$. lentis race 0 isolate CT-30 (Banniza et al., 2018) at $3 \mathrm{~mL}$ per plant using an airbrush. Individual plants were scored for anthracnose severity at 8-10 days post inoculation (dpi) using a 0 to 10 rating scale with $10 \%$ increments. The final disease score from each plant was the mean score per replicate and the data were converted to percent disease severity using the class midpoints for statistical analysis.

\section{Phenotyping for stemphylium blight resistance}

Six seeds of each individual line of the LABC-01 population were sowed in a $10-\mathrm{cm}$ plastic pots filled with SUNSHINE Mix \#4 plant growth medium and arranged in RCBD with three replicates. Two weeks post emergence, plants were thinned to four plants per replicate and fertilized once every week using $3 \mathrm{gL}^{-1}$ of soluble $\mathrm{N}: \mathrm{P}: \mathrm{K}(20: 20: 20)$ PlantProd $^{\circledR}$ fertilizer $(\mathrm{Nu}-$ Gro Inc., Brantford, ON, Canada). Cultivars Eston (Slinkard, 1981) and CDC Glamis (Vandenberg et al., 2002) were used as resistant and susceptible checks, respectively.

A culture stock of the aggressive S. botryosum SB19 isolate collected from Southeast Saskatchewan was obtained from the Plant Pathology Laboratory, USask for mass spore production following a procedure described by Caudillo-Ruiz (2016). Plants were spray-inoculated 
at the pre-flowering stage with approximately $3 \mathrm{~mL}$ of conidial suspension per plant at a concentration of $1 \times 10^{5}$ conidia $\mathrm{mL}^{-1}$ using an airbrush (Badger Airbrush, model TC 20, USA). Two droplets of Tween ${ }^{\circledR} 20$ (Sigma, Saint Louis, MO, USA) were added to every $1000 \mathrm{~mL}$ of suspension before inoculation to help reduce the surface tension of water and promote plant tissue contact. Plants were placed in an incubation chamber for seven days. Two humidifiers (Vicks Fabrique Paz Canada, Inc., Milton, ON, Canada) were placed in the incubation chamber to ensure $90-100 \%$ relative humidity for infection and disease development. Blocks were inoculated over time.

Disease severity was assessed visually at 7 dpi using a semi-quantitative rating scale (0-10) where 0 , healthy plants; 1 , few tiny lesions; 2 , a few chlorotic lesions; 3 , expanding lesions on leaves, onset of leaf drop; 4, 1/5th of nodes affected by lesions and leaf drop; 5, 2/5th of nodes affected; 6, 3/5th of nodes affected; 7, 4/5th of nodes affected; 8, all leaves dried up; 9, all leaves dried up but stem green; and 10, plant completely dead. Disease severity was assessed on single plants within the experimental unit (pot). For each genotype, four single plants per replicate pot were assessed. Disease severity data was analyzed using the median disease severity score for each genotype.

\section{Data analyses}

Statistical analyses were conducted for both anthracnose and stemphylium blight severity using SAS software (SAS 9.4, SAS Institute, Cary, North Carolina, 2011). Normality and variance homogeneity of the residuals were tested using the Shapiro-Wilk normality test and Levene's test for homogeneity, respectively. The data did not fit the assumptions of a Gaussian distribution and were normalised using a lognormal distribution in the GLIMMIX procedure. Genotypes 
were treated as fixed effect and blocks as random effect and significance of variances were declared at $5 \%$ significance level. Least square means were estimated for genotype using LSMEANS statements.

\section{Results and discussion}

In this study we developed a lentil advanced backcross population to explore the valuable genetic variation introgressed from lentil wild relative L. ervoides into adapted cultivar CDC Redberry. L. ervoides accession L-01-827A, the parent to the interspecific LR-59-81, has previously shown adaptation to drought (Gorim and Vandenberg, 2017) and resistance to diseases such as ascochyta blight (Tullu et al., 2010), stemphylium blight (Podder et al., 2013), anthracnose (Vail et al., 2012; Gela et al., 2020), and the parasitic weed broomrape (Orobanche crenata Forsk.) (Bucak et al., 2014). Our results revealed variation for desirable traits in the LABC-01 population that inherited from L-01-827A in the cultivated lentil background including disease resistance and phenological traits.

The LABC-01 population could possibly combine important key traits from L. ervoides for lentil genetic improvement as a pre-breeding genetic source and as a valuable resource on which to conduct further genetic studies. Our data showed that $\mathrm{BC}_{2} \mathrm{~F}_{3: 4}$ generation had a continuous distribution for days to flowering (Supplemental Figure S1) and also segregated for morphological traits such as flower colour (191 white: 26 purple), seed coat colour (190 gray: 27 tan), and seed coat pattern (185 absent: 32 marbled). Vail (2010) and Chen (2018) have reported segregation of several agronomic and phenotypic characteristics including plant vigour, yield and its components in the genetic populations derived from LR-59-81 or L-01-827A. A similar trend was also reported for seed iron concentration (Podder, 2018). Multi-location evaluation of 
LABC-01 lines will be considered necessary for genetic analysis of these traits and selection of advanced lines for the lentil breeding programs.

Significant variation for anthracnose race 0 resistance was observed among the 217 LABC-01 individuals $(\mathrm{F}-\mathrm{value}=3.98, P<0.0001)$. The LR-59-81 had a resistant reaction with a mean disease severity of $36 \%$, whereas the recurrent parent CDC Redberry showed susceptible reactions with a mean of $85 \%$. A large number of the LABC-01 individuals showed to be susceptible to race 0 . The disease severity ranged from $17-95 \%$ with a mean of $70.2 \%$. Transgressive variation for race 0 resistance relative to that of the resistant LR-59-81 was observed (Figure 2A) which is consistent with the findings (Fiala et al., 2009; Tullu et al., 2013), who reported the transgressive segregation and skewed distributions of lines toward the higher level of disease severity. Two pathogenic races of anthracnose (races 0 and 1 ) have been described (Buchwaldt et al., 2004). Resistance to race 1 is abundant in cultivated lentil germplasm, however, resistance to the more virulent race 0 is mainly limited to L. ervoides (Tullu et al., 2006; Barilli et al., 2020; Gela et al., 2020). Transfer of race 0 resistance alleles into the cultivated background could widen the lentil breeding genepool and provide benefits for cultivar development.

Significant variation in stemphylium blight severity was observed among the 217 LABC-01 individuals $(\mathrm{F}-\mathrm{value}=1.81, P<0.0001)$. The resistant line, LR-59-81, had significantly less disease severity (2.32) compared to the resistant check cv. Eston (4.16) and recipient parent CDC Redberry (5.13). The distribution of disease severity as a measure of stemphylium blight response for LABC-01 lines showed continuous variation ranging from 1.59 to 5.80 (Figure 2B), suggesting polygenic regulation of stemphylium blight severity. None of the LABC-01 individuals had significantly less disease than the resistant parent LR-59-81 (Supplementary 
Table S1). This observation is consistent with the findings of Adobor et al. (2020) who also reported the absence of resistant transgressive segregants in L. ervoides interspecific population screened for stemphylium blight resistance in the greenhouse, growth chamber and the field conditions. A high proportion of the LABC-01 individuals (144) had similar disease severity when compared to the resistant parental line LR-59-81, indicating that resistance genes were transferred from the resistant parent to LABC-01 individual lines (Supplementary Table S1).

Understanding the genetic architecture of the favourable traits from the wild germplasm provides breeders information that can aid in the introgression of the traits while avoiding linkage drag of deleterious characteristics of the wild species (Tanksley and Nelson, 1996). The LABC-01 population can be used for preliminary QTL mapping and genetic characterization of agronomic traits and disease resistance that have been introgressed into CDC Redberry. Since no selection was carried out during population creation, some of the LABC-01 lines may be of interest as starting materials for the development of fixed introgression populations for specific traits of interest (Prohens et al., 2017). For instance, QTL analysis can be conducted with the anthracnose race 0 and stemphylium blight data and then the identified markers can be used to facilitate the development of introgression lines (ILs) such chromosome segment substitution lines (CSSLs) and/or near isogenic lines (NILs) by means of marker-assisted selection. The ILs are important for fine QTL mapping studies and developing genetically characterized elite materials that can be directly incorporated into breeding programs (Zamir, 2001; Eduardo et al., 2005, Tian et al., 2006). The present population is being genotyped using an exome capture array described by Ogutcen et al. (2018) which will provide a valuable genetic tool for collaborative lentil research. The plant materials are currently managed and stored at the Crop Development Centre, University of Saskatchewan, Saskatoon, Canada. 


\section{Acknowledgements}

The authors gratefully acknowledge funding from the Natural Sciences and Engineering

Research Council of Canada (NSERC) Industrial Research Chair Program, the Saskatchewan

Pulse Growers, and the University of Saskatchewan. We are also thankful for the technical assistance of the Pulse Pathology lab staff and Pulse Crop Breeding and Genetics group at the University of Saskatchewan.

\section{References}

Adobor S, Podder R, Banniza S and Vandenberg A (2020) Evaluation of resistance to stemphylium blight in interspecific recombinant inbred lines derived from Lens culinaris $\times$ Lens ervoides. Plant Genetic Resources 18: 251-258.

Banniza S, Warale R, Meant J, Cohen-Skali A, Armstrong-Cho C and Bhadauria V (2018) The long path to understanding the host-pathogen interactions of Colletotrichum lentis on lentil. Canadian Journal of Plant Pathology 40(2): 199-209.

Barilli E, Moral J, Aznar-Fernández T and Rubiales D (2020) Resistance to anthracnose (Colletotrichum lentis, race 0) in Lens spp. germplasm. Agronomy 10: 1799.

Bett K, Ramsay L, Chan C, Sharpe A, Cook D, Penmetsa RV et al (2016) Lentil 1.0 and beyond. In: PAG XXIV: Plant and animal genomics conference, 8-13 January 2016, San Diego, California, USA.

Bhanu AN, Gokidi Y and Singh MN (2017) Advanced backcross QTL method: a brief overview. Trends in Biosciences 10: 20-25.

Bucak B, Bett K, Banniza S and Vandenberg A (2014) Transfer of resistance to broomrape (Orobanche crenata) from Lens ervoides to cultivated lentil. In: $6^{\text {th }}$ International Food Legume Research Conference (IFLRCVI), 7-11 July 2014, Saskatoon, Canada, p. 62.

Buchwaldt L, Anderson KL, Morrall RAA, Gossen BD and Bernier CC (2004) Identification of lentil germplasm resistant to Colletotrichum truncatum and characterization of two pathogen races. Phytopathology 94: 236-243. 
Caudillo-Ruiz KB (2016) Characterization of the stemphylium blight pathogens and their effect on lentil yield. MSc Dissertation, University of Saskatchewan, Saskatoon, Canada.

Chen L (2018) Assessing impacts of crop-wild introgression in lentil using interspecific Lens species recombinant inbred line populations. PhD Dissertation, University of Saskatchewan, Saskatoon, Canada.

Dempewolf H, Baute G, Anderson J, Kilian B, Smith C and Guarino L (2017) Past and future use of wild relatives in crop breeding. Crop Science 57: 1070-1082.

Eduardo I, Arús P and Monforte AJ (2005) Development of a genomic library of near isogenic lines (NILs) in melon (Cucumis melo L.) from the exotic accession PI161375. Theoretical and Applied Genetics 112: 139-148.

Erskine W, Adham Y and Holly L (1989) Geographic distribution of variation in quantitative traits in a world lentil collection. Euphytica 43: 97-103.

Erskine W, Tufail M, Russell A, Tyagi MC, Rahman MM and Saxena MC (1994) Current and future strategies in breeding lentil for resistance to biotic and abiotic stresses. Euphytica 73: 127135.

Food and Agriculture Organization of the United Nations (2021) FAOSTAT, Crops. http://faostat3.fao.org (Accessed: 9th January 2021).

Fiala JV, Tullu A, Banniza S, Séguin-Swartz G, Vandenberg A (2009) Interspecies transfer of resistance to anthracnose in lentil (Lens culinaris Medik.). Crop Science 49: 825-830.

Frischa M, Bohna M and Melchinger AE (1999) Comparison of selection strategies for markerassisted backcrossing of a gene. Crop Science 39: 1295-1301.

Fulton TM, Beck-Bunn T, Emmatty D, Eshed Y, Lopez J, Petiard V, Uhlig J, Zamir D and Tanksley SD (1997) QTL analysis of an advanced backcross of Lycopersicon peruvianum to the cultivated tomato and comparisons with QTLs found in other wild species. Theoretical and Applied Genetics 95: 881-894.

Gela TS, Banniza S and Vandenberg A (2020) Lack of effective resistance to the virulent race of Colletotrichum lentis in Lens culinaris Medikus subsp. culinaris. Plant Genetic Resources 18: $81-87$. 
Gorim LY and Vandenberg A (2017) Evaluation of wild lentil species as genetic resources to improve drought tolerance in cultivated lentil. Frontiers in Plant Science 8: 1129.

Gupta D and Sharma SK (2006) Evaluation of wild Lens taxa for agro-morphological traits, fungal diseases and moisture stress in northwestern Indian hills. Genetic Resources and Crop Evolution 53: 1233-1241.

Hajjar R and Hodgkin T (2007) The use of wild relatives in crop improvement: A survey of developments over the last 20 years. Euphytica 156: 1-13.

Khazaei H, Caron CT, Diapari M, Fedoruk M, Vandenberg A, Coyne CJ, McGee R and Bett KE (2016) Genetic diversity of cultivated lentil (Lens culinaris Medik.) and its relation to the world's agro-ecological zones. Frontiers in Plant Science 7: 1093.

Ogutcen E, Ramsay L, von Wettberg EB and Bett KE (2018) Capturing variation in Lens (Fabaceae): Development and utility of an exome capture array for lentil. Applications in Plant Sciences 6: e01165.

Podder R (2018) Iron biofortification and fortification of lentil (Lens culinaris Medik.). PhD Dissertation, University of Saskatchewan, Saskatoon, Canada.

Podder R, Banniza S, and Vandenberg A (2013) Screening of wild and cultivated lentil germplasm for resistance to stemphylium blight. Plant Genetic Resources 11: 26-35.

Pratap A, Das A, Kumar S and Gupta S (2021) Current perspectives on introgression breeding in food legumes. Frontiers in Plant Science, in press. doi:10.3389/fpls.2020.589189

Prohens J, Gramazio P, Plazas M, Dempewolf H, Kilian B, Díez MJ, Fita A, Herraiz FJ, RodríguezBurruezo A, Soler S, Knapp S and Vilanova S (2017) Introgressiomics: A new approach for using crop wild relatives in breeding for adaptation to climate change. Euphytica 213: 1-20.

SAS Institute, Inc. (2011) SAS language and procedure: Usage version 9.4. SAS Institute, Inc., Cary, $\mathrm{NC}, \mathrm{USA}$.

Schmalenbach I, Korber N and Pillen K (2008) Selecting a set of wild barley introgression lines and verification of QTL effects for resistance to powdery mildew and leaf rust. Theoretical and Applied Genetics 117: 1093-1106. 
Singh M, Bisht IS, Kumar S, Dutta M and Chander K (2014) Global wild annual Lens collection: a potential resource for lentil genetic base broadening and yield enhancement. Plos ONE 9: e107781.

Singh M, Rana JC, Singh B, Kumar S, Saxena DR, Saxena A, Rizvi AH and Sarker A (2017) Comparative agronomic performance and reaction to fusarium wilt of Lens culinaris $\times$ L. orientalis and L. culinaris $\times$ L. ervoides derivatives. Frontiers in Plant Science 8: 1162.

Slinkard AE (1981) Eston lentil. Canadian Journal of Plant Science 61: 733-734.

Taguchi-Shiobara F, Ozaki H, Sato H, Maeda H, Kojima Y, Ebitani T and Yano M (2013) Mapping and validation of QTLs for rice sheath blight resistance. Breeding Science 63: 301-308.

Tanksley SD and Nelson JC (1996) Advanced backcross QTL analysis: a method for the simultaneous discovery and transfer of valuable QTLs from unadapted germplasm into elite breeding lines. Theoretical and Applied Genetics 92: 191-203.

Tanksley SD, Young ND, Paterson AH and Bonierbale MW (1989) RFLP mapping in plant breeding: new tools for an old science. Nature Biotechnology 7: 257-264.

Tian F, Li DJ, Fu Q, Zhu FZ, Fu YC, Wang XK and Sun CQ (2006) Construction of introgression lines carrying wild rice (Oryza rufipogon Griff.) segments in cultivated rice (Oryza sativa L.) background and characterization of introgressed segments associated with yield-related traits. Theoretical and Applied Genetics 112: 570-580.

Tullu A, Banniza S, Tar'an B, Warkentin T and Vandenberg A (2010) Sources of resistance to ascochyta blight in wild species of lentil (Lens culinaris Medik.). Genetic Resources and Crop Evolution 57: 1053-1063.

Tullu A, Bett K, Banniza S, Vail S and Vandenberg A (2013) Widening the genetic base of cultivated lentil through hybridization of Lens culinaris 'Eston' and L. ervoides accession IG 72815. Canadian Journal of Plant Science 93: 1037-1047.

Tullu A, Buchwaldt L, Lulsdorf M, Banniza S, Barlow B, Slinkard AE, Sarker A, Tar'an B, Warkentin T and Vandenberg A (2006) Sources of resistance to anthracnose (Colletotrichum truncatum) in wild Lens species. Genetic Resources and Crop Evolution 53: 111-119.

Tullu A, Diederichsen A, Suvorova G and Vandenberg A (2011) Genetic and genomic resources of lentil: status, use and prospects. Plant Genetic Resources 9: 19-29. 
Vail S, Strelioff JV, Tullu A and Vandenberg A (2012) Field evaluation of resistance to Colletotrichum truncatum in Lens culinaris, Lens ervoides, and Lens ervoides $\times$ Lens culinaris derivatives. Field Crops Research 126: 145-151.

Vail SL (2010) Interspecific-derived and juvenile resistance to anthracnose in lentil. $\mathrm{PhD}$ Dissertation, University of Saskatchewan, Saskatoon, Canada.

Vandenberg A, Banniza S, Warkentin TD, Ife S, Barlow B, McHale S, Brolley B, Gan Y, McDonald C, Bandara M and Dueck S (2006) CDC Redberry lentil. Canadian Journal of Plant Science 86: 497-498.

Vandenberg A, Kiehn FA, Vera C, Gaudiel R, Buchwaldt L, Dueck S, Morrall RAA, Wahab J and Slinkard AE (2002) CDC Glamis lentil. Canadian Journal of Plant Science 82: 103-104.

Wong MML, Gujaria-Verma N, Ramsay L, Yuan HY, Caron C, Diapari M, Vandenberg A and Bett KE (2015) Classification and characterization of species within the genus Lens using genotyping-by-sequencing (GBS). PLOS ONE 10: e0122025.

Yuan HY, Saha S, Vandenberg A and Bett KE (2017) Flowering and growth responses of cultivated lentil and wild Lens germplasm toward the differences in red to far-red ratio and photosynthetically active radiation. Frontiers in Plant Science 8: 386.

Yun SJ, Gyenis L, Bossolini E, Hayes PM, Matus I, Smith KP, Steffenson BJ, Tuberosa R and Muehlbauer GJ (2006) Validation of quantitative trait loci for multiple disease resistance in barley using advanced backcross lines developed with a wild barley. Crop Science 46: 1179_ 1186.

Zamir D (2001) Improving plant breeding with exotic genetic libraries. Nature Reviews Genetics 2: 983-989. 
Table 1. Disease response and morphological characteristics of parental lines of the LABC-01 population.

\begin{tabular}{|c|c|c|c|}
\hline Characteristics & CDC Redberry & $\begin{array}{l}\text { LR-59-81/L- } \\
\text { 01-827A }\end{array}$ & Reference \\
\hline \multicolumn{4}{|l|}{ Disease resistance } \\
\hline Anthracnose race 0 & Susceptible & Resistant & Vail et al. (2012), Gela et al. (2020) \\
\hline Anthracnose race 1 & Partially Resistant & Resistant & Banniza et al. (2018) \\
\hline Ascochyta blight & Resistant & Resistant & Tullu et al. (2010) \\
\hline Stemphylium blight & Susceptible & Resistant & Podder et al. (2013) \\
\hline Days to flower & Late & Early & This study \\
\hline Days to maturity & Late & Early & Chen (2018) \\
\hline Seed cotyledon colour & Red & Red & This study \\
\hline Seed coat color/pattern & Gray/unpatterned & $\begin{array}{l}\text { Brown/black } \\
\text { marble }\end{array}$ & This study \\
\hline Seed weight & High & Low & Chen (2018) \\
\hline Flower colour & $\begin{array}{l}\text { White with light blue } \\
\text { veins }\end{array}$ & Purple & This study \\
\hline Plant height & Tall & $\begin{array}{l}\text { Short/weak } \\
\text { stem }\end{array}$ & Chen (2018) \\
\hline
\end{tabular}




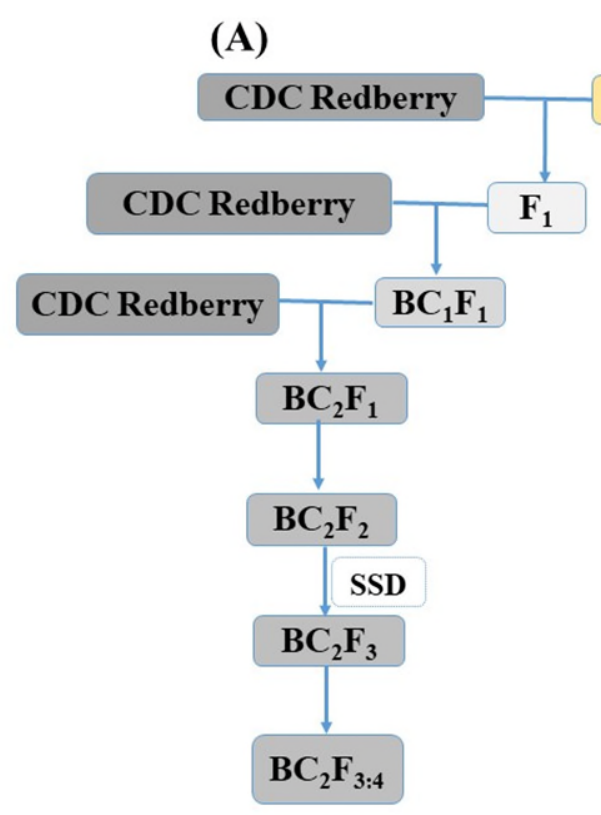

(B)

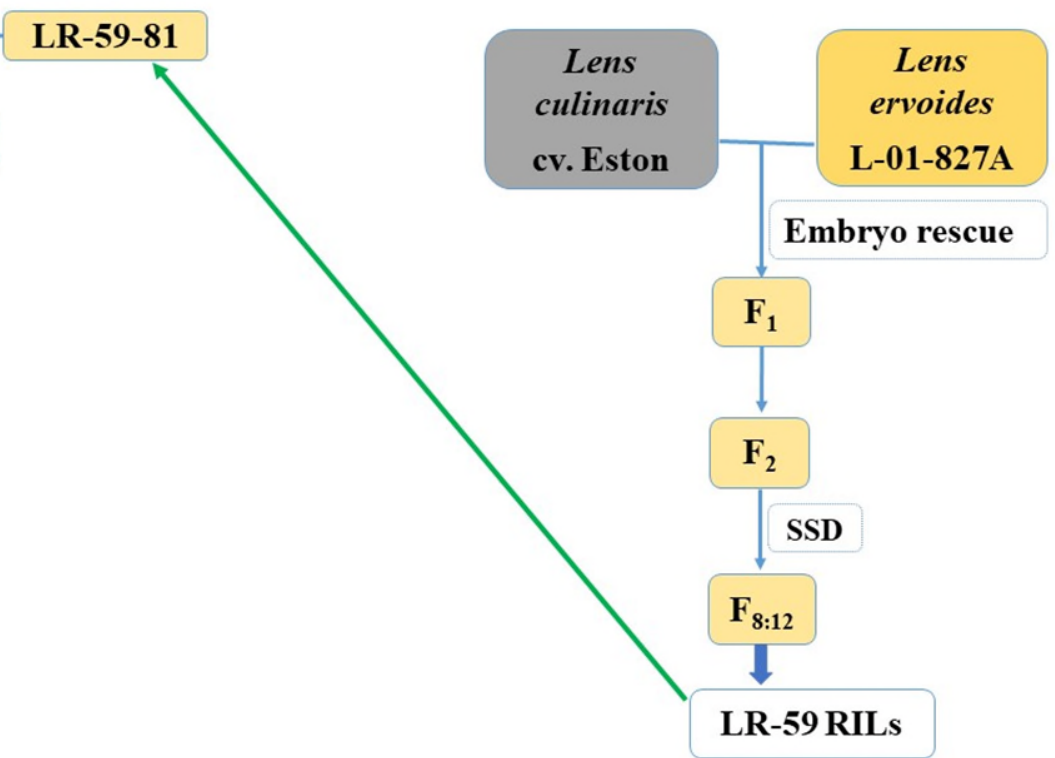

Figure 1. Schematic diagram of lentil advanced backcross mapping population (LABC-01) development (A) and the pedigree of the LR-59-81 (B). SSD, single seed descent. 
(A)

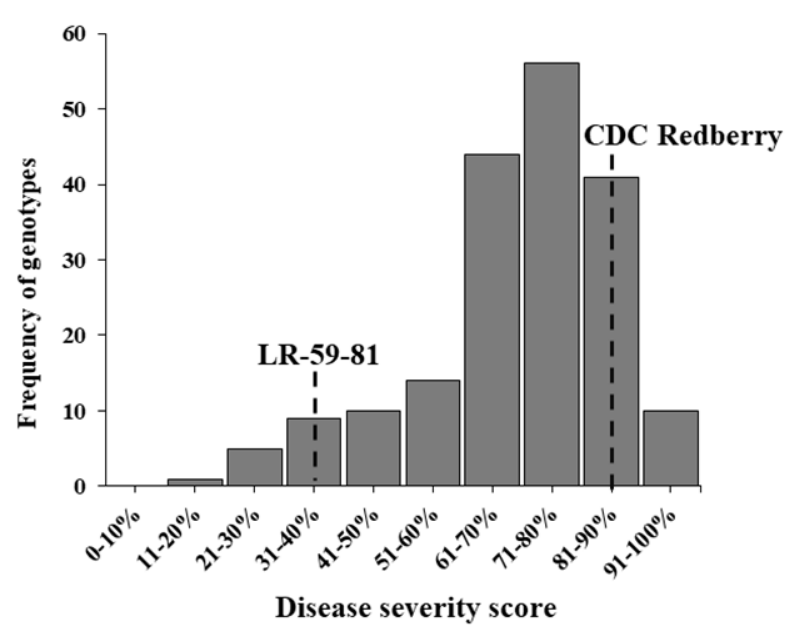

(B)

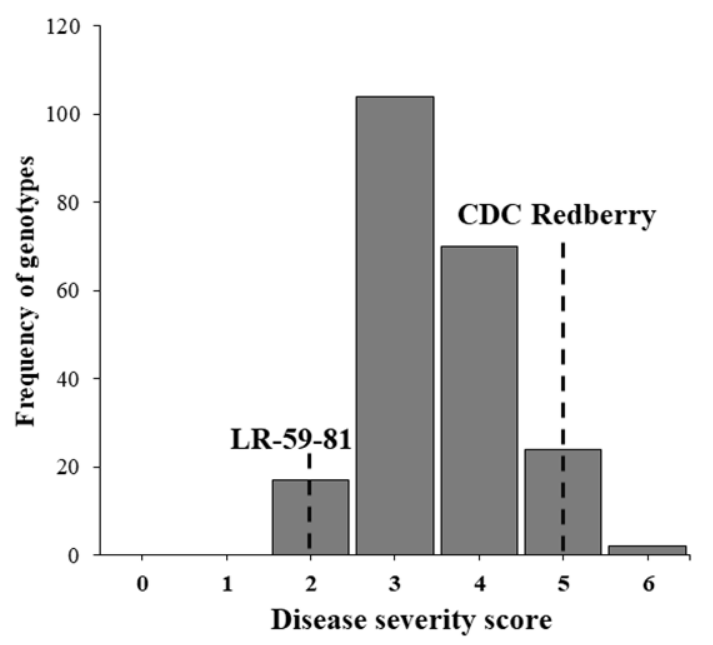

Figure 2. Frequency distribution of mean anthracnose race $0(\mathrm{n}=217, P(W)=0.001)(\mathbf{A})$ and stemphylium blight severity $(\mathrm{n}=217, P(W)=0.018)(\mathbf{B})$ for LABC-01 population at $\mathrm{BC}_{2} \mathrm{~F}_{3: 4}$ generation under growth chamber condition. The vertical lines indicate the average disease severity of the parents. $P(W), \mathrm{P}$ value of the Shapiro-Wilk test for normality. 